\title{
Silver-chlorexidineliquid is effective to sterilize screw retaining abutment to implant space in already inserted fixture: An in vitro study
}

Lauritano Dorina1 ${ }^{1}$ Girardi Ambra², Bignozzi Carlo Alberto3, Napoleone Claudio ${ }^{4}$, De Lellis Riccardo ${ }^{5}$, Carinci Francesco

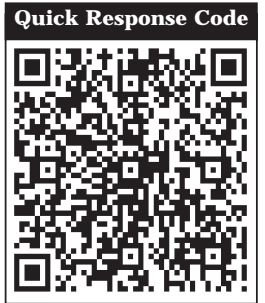

doi: $10.5866 / 2015.7 .10008$

${ }^{1}$ Department of Translational medicine and surgery, Neuroscience Centre of Milan, NeuroMi, University of Milan-Bicocca, Milan, Italy.

${ }^{2}$ Department of Experimental, Diagnostic and Speciality Medicine, University of Bologna, Via Belmeloro 8, 40126 Bologna, I taly

${ }^{3}$ Chef of Department of Chemistry, University of Ferrara, Via Luigi Borsari, 46 - 44121 Ferrara, Italy ${ }^{4 \& 5}$ Department of Dentistry, Mangioni Hospital, via Leonardo da Vinci, 4923900 Lecco, I taly

${ }^{6}$ Department of Morphology, Surgery and

Experimental Medicine, University of Ferrara, Via

Luigi Borsari, 46 - 44121 Ferrara, Italy

\section{Article Info:}

Received: J anuary 11, 2015

Review Completed: February 10, 2015

Accepted: March 12, 2015

Available Online: April, 2015 (www.nacd.in)

(c) NAD, 2015 - All rights reserved

\section{Email for correspondence:}

crc@unife.it

\begin{abstract}
:
Contamination of screw retaining abutment to implant space (SRAIS) creates an infected room at the implant abutment junction (IAJ ) that can cause or maintain peri-implantitis. Aim of the present study is to determine whether the treatment of SRAIS with silverclorexidine liquid (named SBC-40) is able to sterilize SRAIS.
\end{abstract}

Materials and methods: A total of eight implants were used (E dierre Implant System, Edierre SpA, Genova, Italy). The SRAIS of four fixtures were firstly contaminated with 10 micro-litres of pure bacteria (i.e. genetically modified Escherichia coli). Subsequently SRAIS were treated with SBC-40 for 20 seconds and then replaced with Lysogeny Broth (LB). The remaining four implants werejust filled with LB. Abutment were then screwed. All 8 fixtures were placed in tubes and immerged in LB plus E. coli to cover outer implant-abutment junction (IAJ). After 24 hours IAJ were opened and liquid collected from SRAIS by using paper tips. Same sampling was performed in LB out of implants. The tips were immerged in sterile LB and bacteria viability was determined by measuring their Optical Density (OD) at three time points.

Results: In untreated implants, bacteria grew (internally and externally) for the first 48 hours but subsequently they started to die. In treated implants, instead, bacteria grew just in the space surrounding fixtures suggesting that, even if bacteria were able to enter in SRAIS, they immediately died, thanks to the presence of SBC-40.

Conclusions: SBC-40 is potentially able to sterile the SRAIS in fixtures already inserted in patients.

Key words: Bone resorption, implant-abutment connection, microbiological leakage, peri-implantitis.

\section{INTRODUCTION}

Contamination of screw retaining abutment to implant space (SRAIS) and microbial leakage between implant-abutment junction (IAJ ) can cause or maintain peri-implantitis. ${ }^{1}$ Many implant systems have been created in order to prevent bacterial penetration/leakage and bone resorption at IAJ level, but, even in the most advanced implant 
systems, there is no sealant connection. ${ }^{2}$ Microbial leakage is an important factor for chronic inflammatory infiltration and marginal bone resorption. ${ }^{3} \mathrm{New}$ designs of IAJ aim to improve precise tight mechanical connection and thus minimize the bacterial leakage. This process is technically very difficult as bacteria are around 1$10 \mu \mathrm{m}$ in length. ${ }^{4}$

The most successful two-pieces dental implant systems use screw-retained or cemented-retained abutments. This system provides two interfaces: one between implant and abutment and the other between abutments and prosthetic crown, with a significant accumulation of bacterial bio-film. When IAJ is under loading, the size of gaps increases due to micro-movements which also have a pump effect, sucking bacteria from the external environment or pumping them around implant. ${ }^{5}$

Some studies quantify microbiological penetration between micro-gaps at IAJ level, showing that there is no sealing IAJ till now. ${ }^{6,7}$ Antibacterial agents has been studied to cleaning SRAIS, but none have been demonstrated to be completely effective. ${ }^{8}$ Thus a new silver-clorexidine liquid named SBC-40 is here investigated in an in vitro model to verify its effectiveness in sterilising SRAIS.

\section{Material and Methods}

\section{Silver-clorexidine liquid named SBC-40}

The liquid is an aqueous solution containing a thermally and photochemically stable anionic silver complex, where the silver ion is coordinated to the sulfur of the 2-mercapto-5-benzoimidazole sulfonic ligand (Figure 1A). Pharmaceutical compositions based on photochemically stable silver complexes chlorexidineand cationic surfactants; (PCT/I B 2013/ 054649) in mixture with didecyldimethylammonium chloride (Figure 1B) and with chlorhexidine digluconate (Figure 1C).

\section{Preparation of the anionic complex $\left(\mathrm{Ag}^{+}-\left[\mathrm{L}^{-}\right.\right.$ $\left.\mathrm{Na}^{+}\right]$) as Sodium salt.}

The anionic complex $\left(\mathrm{Ag}^{+}-\left[\mathrm{L}^{-} \mathrm{Na}^{+}\right]\right)$with $\left[\mathrm{L}^{-} \mathrm{Na}^{+}\right]$ = 2-Mercapto-5-benzimidazolesulfonic acid sodium salt was prepared by addition of the ligands [ $\mathrm{L}-\mathrm{Na}^{+}$] to an aqueous solution containing a stechiometric amount of $\mathrm{AgNO}_{3}$. The product, formed instantly, was preci pitated by addition of ethanol/diethyl ether and the solid dried at $50{ }^{\circ} \mathrm{C}$ for $12 \mathrm{hr}$ in a ventilated oven.
Stability tests did not show any change in colour or composition after 12 months to ambient light exposure. In comparable conditions, solutions of Silver salts, such as nitrate, acetate, perchlorate or hesafluorophosphate, showed formation of a black $\mathrm{Ag}^{\circ}$ precipitate after few minutes.

\section{Preparation of SBC-40}

The product is composed by an aqueous solution containing the anionic silver complex, where silver ions are present at $0.00022 \%$, didecyldimethylammonium chloride at $0.57 \%$ and of chlorhexidine digluconate at $0.11 \%$. The product can be prepared by direct dissolution of the different components in sterile water (Pharmaceutical compositions based on photochemically stable silver complexes chlorexidine and cationic surfactants. PCT/I B2013/054649).

\section{Implants treatment}

To verify the antibacterial power of SBC-40 in implant already inserted in patients, an in vitro model was developed. A genetically modified Escherichia coli containing synthetic DNA target sequences in their plasmid was used. Plasmids contain two sequences specific for two bacterial species (i.e. Porphyromonas gingivalis and Tannerella forsythia) as well as two genes for antibiotic resistance (Kanamycin and Ampicillin).

Bacteria were cultured in Lysogeny Broth (LB) with both Kanamycin and Ampicillin (at a final concentration of $50 \mathrm{ug} / \mathrm{ml}$ ), in order to avoid the growth of non-specific bacteria. Cultures were then let at $37^{\circ} \mathrm{C}$ for $12-18$ hours in a shacking incubator.

A total of eight implants were used (Edierre Implant System, Edierre SpA, Genova, Italy). A drawn picture of the IAJ is given in Figure 2. The SRAIS of four fixtures were contaminated with 10 micro-litres of pure bacteria and subsequently washed for 20 seconds with SBC-40. Then SBC-40 was replaced with pure LB and abutment screwed. The remaining four implants were not treated with SBC-40 and just filled with LB. Subsequently, 20 micro-litres of $E$. coli culture were used to "contaminate" fresh LB contained in a microcentrifuge tube where implants were placed. The volume of the solution was enough to submerge the IAJ .Tubes werethen incubated at $37^{\circ} \mathrm{C}$ for 24 hours in a heater, in order to allow bacterial growth. 
To check for the presence of any bacterial contamination, a negative control containing only LB with antibiotics both inside and outside implant was included in the study.

Twenty-four hours later, each implant was opened and samples were collected by dipping a paper probe both outside and inside implants (Figure 3). A total of 4 paper probes for implant were collected. Two out of these four probes were used to measure the bacteria optical density outside the implant, and the remaining were employed for the internal measurement.

\section{Optical density (OD) measurement}

Paper probes were put, in a pair, in a microcentrifuge tube with 200ul of LB with selective antibiotics, and let at $37^{\circ} \mathrm{C}$ in a heater for optical density measurement at four time point: $24,48,72$ and 96 hours. Bacterial OD600 was measured by using Nano-Drop 2000c spectrophotometer (Thermo scientific, Wilmington, USA). For each sample luL of $L B$ with or without bacteria was measured. Sterile LB broth with antibiotic, instead, was used to blank the spectrophotometer.

\section{Statistical analysis}

To evaluate if the different bacterial growth among SBC-40 treated and untreated implants was statistically significant, Student's t-test was applied on average OD both for external and internal measurement, at each time point.

\section{RESULTS}

Figure 4 shows the bacterial growth by measuring optical density at 600nm (OD600). Average OD values between treated and untreated implants were compared, between internal and external medium at each time point. In untreated implants, bacteria grew (internally and externally) for the first 48 hours but subsequently they started to dye, probably as a consequence of nutrient consumption. In SBC-40 treated implants, bacteria grew just out of implants suggesting that, even if bacteria were able penetrating the screw-retainingimplant-space, they immediately died thanks to the presence of SBC-40.

Comparing treated and untreated-implants, differences in bacterial growth were statistically significant at 24, 48 and 72 hours. After 96 hours, in fact, bacteria died both in treated and in untreated implants and thus no difference was detectable
(Table 1). Externally, no differences were revealed (Table 2).

\section{DISCUSSION}

Silver ion is an effective antimicrobial agent and shows a rather broad spectrum of bactericidal activity consistent with different mechanisms of action, which depends on the binding site. For instance, when binding occurs at the bacterial cell wall, ruptures can occur. ${ }^{9}$ When bound to proteins involved in respiration and nutrition of the organism, silver can block these processes with the consequent elimination of the bacteria. ${ }^{10}$ When binding DNA, silver can affect the replication and division of the organism. ${ }^{11}$

Since bacterial passage through IAJ has been demonstrated in several in vitro studies (12-14) and SRAIS is a reservoir of bacteria which potentially cause peri-implantitis, the effect of SBC-40 in sterilizing SRAIS was proven in the present in vitro model.

Colonization of the IAJ is associated to many factors: tight connection between the implant and prosthetic components, torque used to connect abutment to fixture, and overloading after prosthetic rehabilitation. A perfect sealing between implant and abutment was never found (to our best knowledge) and micro-gaps are colonized by periodontal bacteria being risk factor for periimplantitis.

Even if the design of IAJ can limit the bacteria penetration into the internal part of a dental implant, microbiological studies confirmed the passage of bacteria around IAJ at level of periimplant tissues. ${ }^{12,13}$ In an in vitro study, Dias et al demonstrated microbial penetration of IAJ microgap of fixtures with an external hex design. ${ }^{12}$ Cosyn et al studied microbial leakage in different implantabutment connections, showing microbial contamination in implant with an internal connection. ${ }^{13}$ Kotouzis et al evaluated bacterial penetration along the IAJ micro-gap and established bacterial col onization in an in vitro experiment using loading forces. ${ }^{14}$ Other studies investigated microorganism penetration through IAJ in order to find an efficient bacterial seal system. ${ }^{15-18}$ With the twopiece implant system, the abutment is retained to fixture with mechanical methods. This results in gaps and cavities between the IAJ becoming a bacteriological reservoir. This gap favours an 


\section{Table 1: I nner average OD values of SBC40 treated and untreated implants, and their comparison}

\begin{tabular}{lccc}
$\begin{array}{l}\text { Time } \\
\text { point }\end{array}$ & $\begin{array}{c}\text { OD600 } \\
\text { Untreated } \\
\text { Implants }\end{array}$ & $\begin{array}{c}\text { OD600 } \\
\text { Treated } \\
\text { Implants }\end{array}$ & P-value $^{(\mathrm{a})}$ \\
\hline $24 \mathrm{~h}$ & 0,050 & 0,007 & 0,0264 \\
\hline $48 \mathrm{~h}$ & 0,064 & 0,004 & 0,0248 \\
\hline $72 \mathrm{~h}$ & 0,018 & 0,003 & 0,0299 \\
\hline $96 \mathrm{~h}$ & 0,003 & 0,001 & 0,1901 \\
\hline
\end{tabular}

(a) data were considered statistically significant for P-value $\measuredangle 0.05$

A

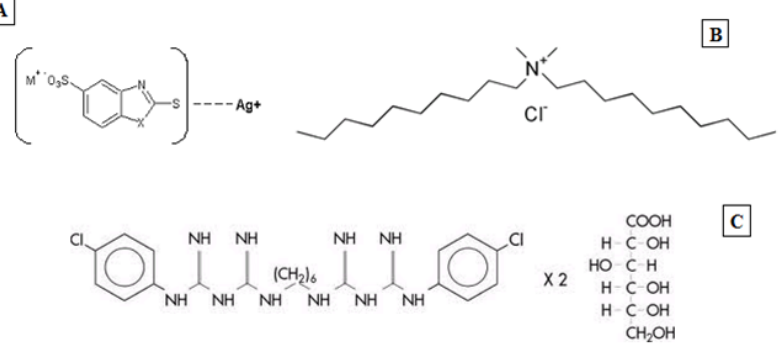

Figure 1: Silver-clorexidine liquid named SBC-40. Silver ion coordinated to the sulfur of the 2-mercapto-5-benzoimidazole sulfonic ligand $(A)$ in a mixture with

Didecyldimethylammonium chloride (B) and Chlorhexidine digluconate $(\mathrm{C})$.
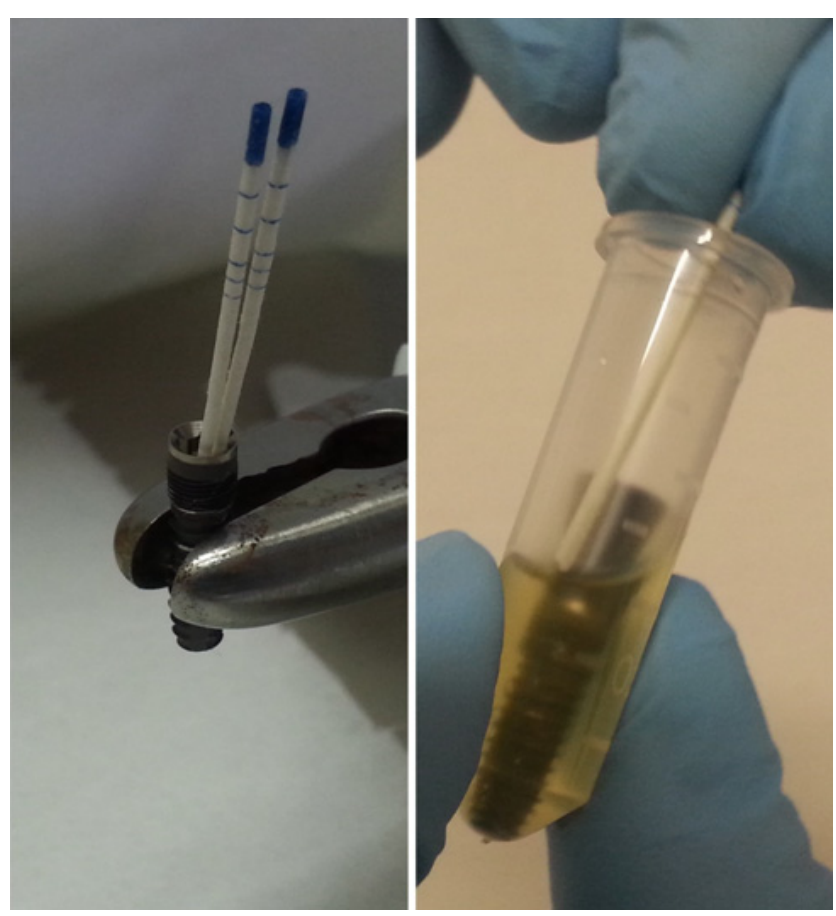

Figure 3: Samples collection- Samples were collected by dipping a paper probe both inside (on the left) and outside (on the right) the implants.

\section{Table 2. Outer average OD values of SBC40 treated and untreated implants, and their comparison.}

\begin{tabular}{lccc}
$\begin{array}{l}\text { Time } \\
\text { point }\end{array}$ & $\begin{array}{c}\text { OD600 } \\
\text { Untreated } \\
\text { Implants }\end{array}$ & $\begin{array}{c}\text { OD600 } \\
\text { Treated } \\
\text { Implants }\end{array}$ & P-value(a) \\
\hline $24 \mathrm{~h}$ & 0,110 & 0,079 & 0,2293 \\
\hline $48 \mathrm{~h}$ & 0,127 & 0,116 & 0,3268 \\
\hline $72 \mathrm{~h}$ & 0,045 & 0,040 & 0,5765 \\
\hline $96 \mathrm{~h}$ & 0,009 & 0,007 & 0,5496 \\
\hline
\end{tabular}

(a)data were considered statistically significant for $\mathrm{P}$-value $\measuredangle 0.05$
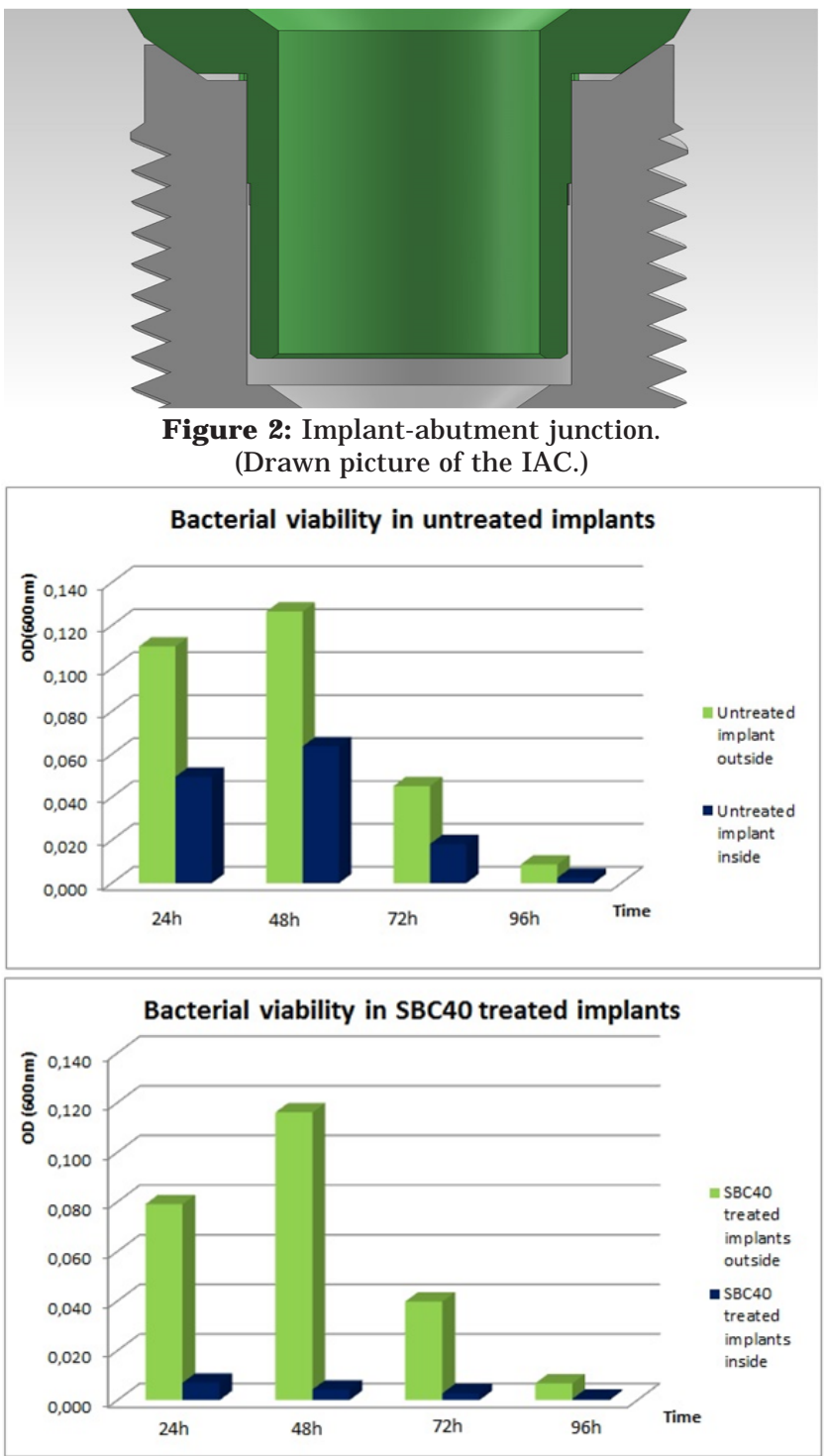

Figure 4: Bacterial viability- Optical density (OD) measurement inside and outside untreated and treated implants, at four different time points. 
inflammatory process in peri-implant tissues. Microbial colonization of the IAJ has consequences as bone resorption as clearly demonstrated by Lazzara in his work on "Platform Switching". ${ }^{19}$

\section{CONCLUSION}

Since there is no IAJ which is sealant, today, a solution able to clean and to sterilize the screw retaining abutment to implant space can be very useful in the dental daily practice. The present report demonstrated that SBC-40 is an effective antibacterial solution in an in vitro model which can be potentially used in already inserted two-piece implants. SBC-40 could be considered a new frontier in the era of peri-implantitis prevention.

\section{REFERENCES}

1. Broggini $N$, McManus LM, J S H, Medina RU, Oates TW, SchenK RK, et al. Persistent acute inflammation at the implant-abutment interface. J ournal Dental Res 2003; 82:232-237.

2. Mombelli A, Decaillet F. The characteristics of biofilms in peri-implant disease. J Clin Periodontol, 2011; 38(11): 203213.

3. Aloise J P, Curcio R, Laporta MZ, Rossi L, da Silva AM, Rapoport A. Microbial leakage through the implantabutment interface of Morse taper implants in vitro. Clin Oral Implants Res 2010; 21:328-335.

4. do Nascimento C, Miani PK, Watanabe E, Pedrazzi V, de Albuqerque RF, J r. In vitro evaluation of bacterial leakage along the implant-abutment interface of an external-hex implant after saliva incubation. Int J Oral Maxillofac Implants 2011; 26:782-787.

5. Piattelli A, Scarano A, Paolantonio M, Assenza B, Leghissa GC, Di Bonaventura G, Catamo G, Piccolomini R. Fluids and microbial penetration in the internal part of cementretained versus screw-retained implant-abutment connections. J Periodontol 2001; 72:1146-11450.

6. D'E rcoleS, Tripodi D, Ravera L, Perrotti V, Piattel li A, I ezzi $G$. Bacterial leakage in morse cone internal connection implants using different torque values: an in vitro study. I mplant Dent 2014; 23(2):175-179.

7. do Nascimento. C, Barbosa. RE, Issa. J P, Watanabe. E, Ito. IY, Albuquerque. RF. Bacterial leakage along the implantabutment interface of premachined or cast components. Int J Oral Maxillofac Surg 2008;177-180.
8. Rimondini L, Marin C, Brunella F, M F. Internal contamination of a 2-component implant system after occlusal loading and provisionally luted reconstruction with or without a washer devic. J Periodontol 2001;1652-1657.

9. Feng QL, Wu J, Chen GQ, Cui FZ, Kim TN, Kim J O. A mechanistic study of the antibacterial effect of silver ions on Escherichia coli and Staphylococcus aureus. J Biomed Mater Res 2000; 52: 662-668.

10. Fox CL, J r., Modak SM. Mechanism of silver sulfadiazine action on burn wound infections. Antimicrob Agents Chemother 1974; 5:582-588.

11. Klueh U, Wagner V, Kelly S, J ohnson A, Bryers J D. Efficacy of silver-coated fabric to prevent bacterial colonization and subsequent device-based biofilm formation. J Biomed Mater Res 2000; 53: 621-631.

12. Dias EC, Bisognin ED, Harari ND, Machado SJ, da Silva CP, Soares GD, Vidigal GM, J r. Evaluation of implantabutment microgap and bacterial leakage in five externalhex implant systems: an in vitro study. Int J Oral Maxillofac I mplants 2012; 27:346-351.

13. Cosyn J , Van Aelst L, Collaert B, Persson GR, De Bruyn H. The peri-implant sulcus compared with internal implant and suprastructure components: a microbi ol ogical analysis. Clin Implant Dent Relat Res 2000; 13:286-295.

14. Koutouzis $\mathrm{T}$, Wallet $\mathrm{S}$, Calderon $\mathrm{N}$, Lundgren $\mathrm{T}$. Bacterial colonization of the implant-abutment interface using an in vitro dynamic loading model. J Periodontol 2011; 82:613618.

15. Koutouzis T, Mesia R, Calderon N, Wong F, Wallet S. The effect of dynamic loading on bacterial colonization of the dental implant fixture-abutment interface: an in vitrostudy. J Oral I mplantol 2014; 40:432-437.

16. Barbosa RE, do Nascimento C, Issa J P, Watanabe E, Ito $I Y$, de Albuquerque RF, J r. Bacterial culture and DNA Checkerboard for the detection of internal contamination in dental implants. J Prosthodont 2009; 18: 376-381.

17. Teixeira W, Ribeiro RF, Sato S, Pedrazzi V. Microleakage into and from two-stage implants: an in vitro comparative study. Int J Oral Maxillofac Implants 2011; 26:56-62.

18. Ricomini Filho AP, Fernandes FS, Strai oto FG, da Silva WJ , Del Bel Cury AA. Preload loss and bacterial penetration on different implant-abutment connection systems. Braz Dent J 2010; 21:123-129.

19. Lazzara RJ , Porter SS. Platform switching: a new concept in implant dentistry for controlling postrestorative crestal bone levels. Int J Periodontics Restorative Dent 2006; 26: 9-17.

\section{Gain quick access to our journal online View our journal at www.nacd.in}

